\title{
Evaluation by computerized morphometry of histopathological alterations of the colon wall in segments with and without intestinal transit in rats ${ }^{1}$
}

\author{
Avaliação por morfometria computadorizada das alterações histopatológicas da parede cólica \\ em segmentos com e sem trânsito intestinal em ratos
}

\author{
Marcos Vieira de Sousa ${ }^{\mathrm{I}}$, Denise Gonçalves Priolli ${ }^{\mathrm{II}}$, Adriana Valim Portes ${ }^{\mathrm{II}}$, Izilda Aparecida Cardinallii ${ }^{\mathrm{IV}}$, José Aires Pereira ${ }^{\mathrm{v}}$, \\ Carlos Augusto Real Martinez ${ }^{\mathrm{VI}}$ \\ ${ }^{\text {I }}$ Fellow Master Degree, Posgraduate Program in Health Sciences, USF, Bragança Paulista, Sao Paulo, Brazil. \\ ${ }^{I I}$ Associate Professor, Posgraduate Program in Health Sciences, USF, Bragança Paulista, Sao Paulo, Brazil. \\ III Graduate student of Medical Course, Scholarship holder of the Scientific Initiation Program (PROBAIC), USF, Sao Paulo, Brazil. \\ Iv Associate Professor and Head of Division of Pathology, USF, Bragança Paulista, Sao Paulo, Brazil. \\ ${ }^{v}$ Assistant Professor, Division of Pathology, USF, Bragança Paulista, Sao Paulo, Brazil. \\ ${ }^{v 1}$ Associate Professor, Posgraduate Program in Health Sciences, USF. Surgeon-in-Chief of São Francisco University Hospital (HUSF), Brazil.
}

\begin{abstract}
Purpose: To evaluate histopathological alterations of the colon wall in segments with and without intestinal transit, by computer-assisted imaging, and to correlate these with the length of time diversion. Methods: Thirty male Wistar rats were subjected to intestinal transit diversion by a proximal colostomy and distal mucosa fistula. The animals were divided into three experimental groups according to how long after the initial surgical procedure they were sacrificed: six, twelve and eighteen weeks. Colon segments with and without transit were subjected to histopathological study. The variables colon crypt length, mucosal ulceration, muscle layer thickness of the muscularis mucosa, submucosa and muscularis propria, vascular congestion, number of caliciform cells, inflammatory grade and degree of inflammation, comparing the two colon segments in the different experimental groups were studied. Intestinal crypt length, muscle layer thickness of the mucosa, submucosa and muscularis propria and caliciform cells were measured by computer-assisted imaging method. Mean equality, variance analysis and correlation tests were used in the statistical analysis, and the significance level was set at 5\%. Results: Comparison between segments with and without transit showed that the latter presented reduced length of colon crypts and increased muscle layer thickness of the muscularis mucosa, submucosa and muscularis propria. There were greater quantities of ulceration of the mucosal and greater degree of inflammation with increasing time without transit. Mucosal ulceration, submucosal vascular congestion, increased thickness of the submucosal and muscularis propria layers, presence of caliciform cells, inflammatory infiltrate and inflammatory grade correlated significantly with the length of time without transit. Conclusions: Histological alterations occurred in all layers of the colon wall, in the segments without intestinal transit. Ulcerations in the intestinal mucosa, increased number of caliciform cells, greater vascular congestion of the submucosal layer and inflammatory reaction were related to increasing length of time without transit.
\end{abstract}

Key words: Colon. Colitis. Colostomy. Image Processing, Computer-Assisted. Rats.

\section{RESUMO}

Objetivo: Avaliar por método de imagem assistida por computador as alterações histopatológicas da parede cólica em segmentos providos e desprovidos de trânsito intestinal e relacioná-las ao tempo de exclusão. Métodos: Trinta ratos Wistar machos foram submetidos à derivação do trânsito no cólon esquerdo por meio de colostomia proximal e fístula mucosa distal. Os animais foram divididos em três grupos experimentais segundo o sacrifício ter sido realizado seis, doze e dezoito semanas após o procedimento cirúrgico inicial. Segmentos dos cólons providos e desprovidos de trânsito foram submetidos a estudo histopatológico. Foram analisadas as variáveis: comprimento das criptas cólicas, ulceração na mucosa, espessura das camadas muscular da mucosa, submucosa e muscular própria, congestão vascular, número de células caliciformes e graduação inflamatória comparando os dois segmentos cólicos nos diferentes grupos experimentais. As variáveis, comprimento das criptas intestinais, espessura das camadas muscular da mucosa, submucosa e muscular própria foram mensuradas por método de imagem assistida por computador. $\mathrm{Na}$ análise estatística foram utilizados testes de igualdade de médias e medianas, análise de variância e correlação estabelecendo-se nível de significância de cinco por cento. Resultados: A exclusão de trânsito mostrou-se associada à redução do comprimento das criptas cólicas, aumento da espessura das camadas muscular da mucosa, submucosa e muscular própria. Verificou-se maior quantidade de ulcerações na mucosa e maior grau de inflamação com o progredir do tempo de exclusão. Houve correlação significante entre as ulcerações da mucosa, congestão vascular da submucosa, aumento da espessura das camadas submucosa e muscular própria, presença de células caliciformes, infiltrado inflamatório, graduação inflamatória e o tempo de exclusão de trânsito. Conclusões: Alterações histológicas ocorrem em todas as camadas da parede cólica, em segmentos sem trânsito intestinal. Ulcerações na mucosa intestinal, aumento no número de células caliciformes, maior congestão vascular na camada submucosa e reação inflamatória estavam relacionadas com o progredir do tempo de exclusão intestinal.

Descritores: Cólon. Colite. Colostomia. Processamento de Imagem Assistida por Computador. Ratos.

${ }^{1}$ Research performed at Posgraduate Program in Health Sciences, Sao Francisco University (USF), Bragança Paulista, Sao Paulo, Brazil. 


\section{Introduction}

Diversion colitis (DC) is defined as an inflammatory process that affects colorectal segments without intestinal transit. This condition was first described in 1981 and, since then, it has been recognized with increasing frequency ${ }^{1,2,3}$. With increasing urban violence leading to greater numbers of anorectal-colonic traumatic events with increasing incidence of colorectal cancer and inflammatory intestinal diseases, operations involving intestinal transit deviation are being performed more frequently. This leads to a proportional increase in the number of patients who are at risk of developing $\mathrm{DC}^{4}$.

Several theories have been put forward to explain the etiopathogenesis of DC. Prominent among these is a theory correlating the appearance of this disease with decreased quantities of short-chain fatty acids (SCFAs) in the intestinal lumen. SCFAs are the principal energy substrate for metabolizing colonocytes ${ }^{5,6}$. In a colon without transit, the absence of fiber coming from the diet impedes the formation of SCFAs and their consequent absorption and metabolic use by the epithelial cells of the colon wall ${ }^{7}$. A deficiency of SCFAs in the intestinal lumen causes an inflammatory process and changes the absorption capacity of the mucosa, thereby causing the loss of its barrier function against translocation of antigens from inside the lumen ${ }^{7,8}$.

The main histopathological alterations found in DC cases relate to the presence of different degrees of inflammation of the colon wall ${ }^{2,6}$. Studies conducted among patients with DC have presented controversial results, thus demonstrating that this disease progresses with a variety of histopathological changes and that there is no characteristic pattern ${ }^{2}$. The most common alterations include mucosal erosion or ulceration, nonspecific chronic inflammatory processes, diffuse nodular lymphoid hyperplasia, cryptitis, inflammatory infiltrate in the lamina propria, mucin depletion in the mucosal epithelium, atrophy of the colon crypts and, more rarely, tissue dysplasia ${ }^{2,6}$. These alterations seem to increase in intensity as the length of time without intestinal transit increases, and they may be reversed once the intestinal transit is reestablished ${ }^{6}$.

Most of the published studies evaluating the histopathological alterations in DC cases have been carried out among human samples. This makes it difficult to achieve uniform analysis, because the underlying disease, the different surgical techniques utilized and the different lengths of time for which the transit is excluded vary significantly between studies ${ }^{9}$. The lack of uniformity in descriptions of the different histopathological characteristics found in DC cases and the heterogeneity of human samples have made it problematic to establish the particular histopathological pattern.

Notwithstanding the known evidence, few studies have so far evaluated DC experimentally. There are doubts regarding the alterations found in the colon wall and their relationship with the length of time of transit exclusion ${ }^{9,10,11}$. Most studies have interpreted the histological alterations encountered in a subjective, dependent and variable manner, according to the pathologist's experience of evaluating such specimens ${ }^{11}$.

The possibility of using an experimental animal model for DC, together with an analysis method that enables objective evaluation, ensures greater faithfulness in interpreting the results found, thereby giving uniformity to the description of the different characteristics seen under the microscope. Variables that can be quantitatively evaluated, such as colon crypt length and muscle layer thickness of the mucosa, submucosa and muscularis propria can be determined more precisely ${ }^{11}$. Devising an experimental model for DC also enables temporal and prospective evaluation of the various inflammatory alterations involved, thereby improving the understanding of the importance of the duration of exclusion in relation to the evolution of this condition. Knowledge of the different histopathological characteristics relating to DC will make it possible to draw up new strategies for treating and preventing this disease, which probably presents progressive incidence and therefore gives rise to increasing social and economic cost.

The aim of the present study was to experimentally evaluate the main histopathological alterations found in excluded colon segments from rats subjected to intestinal deviation, in comparison with the findings from colon segments with transit, and to correlate such alterations with the duration of exclusion.

\section{Methods}

This research was performed in accordance with Federal Law No. 6,638 and the guidelines from the Brazilian College of Animal Experimentation (COBEA). It was granted approval by the Research Ethics Committee of São Francisco University, Bragança Paulista, São Paulo, Brazil.

Thirty male rats of Wistar lineage (Rattus norvegicus albinus) from the central animal house of São Francisco University were used. Their weights ranged from 300 to 380 grams and their mean age was four months. The animals were randomly distributed into three experimental groups of ten animals each, according to how long after the surgical procedure they would be sacrificed: six weeks (group A), 12 weeks (group B) and 18 weeks (group C).

On the day preceding the surgical procedure, the animals were kept fasting, except for water, for 24 hours. They were housed in individual cages, identified by the animal's number, and the postoperative follow-up data was noted on specific record cards.

On the day of the intervention, they were weighed and then anesthetized using $2 \%$ xylazine hydrochloride + ketamine hydrochloride at a dose of $0.1 \mathrm{ml} / 100 \mathrm{~g}$, administered intraperitoneally. After anesthetization, they were restrained on a surgical table in horizontal dorsal decubitus, the abdomen was shaved and an antisepsis procedure was carried out using polyvinylpyrrolidone-iodine (PVPI).

The abdominal cavity was accessed by a medial longitudinal incision of three centimeters in length, and the rectosigmoid portion of the large intestine was identified. With the aid of a pachymeter and after ligature of the vessels of the marginal arcade, the colon was sectioned one centimeter above Peyer's patch. After removing the fecal content that possibly was present, the proximal segment of the sectioned colon was brought to the exterior by means of a circular incision of three millimeters in diameter that was made on the left flank, through the whole abdominal wall. The colostomy was attached using a suture consisting of four separate 6-0 nylon stitches always tied off with three knots. The distal segment of the sectioned large intestine was 
catheterized with a $12 \mathrm{~F}$ polyvinyl catheter attached by ligature with $3-0$ cotton thread and was irrigated with $0.9 \%$ physiological serum until the effluent drained through the animal's anus no longer presented fecal material. After irrigation, the catheter was removed and the distal colon was brought to the exterior as a colostomy on the lower left lateral face of the abdominal wall. This distal colostomy was attached using the same technique as used for the proximal colostomy. The abdominal wall was closed as two layers of suturing (peritoneum and aponeurosis) using continuous stitches of 4-0 polyglycolic acid thread, and the skin was closed using separate 4-0 nylon stitches.

After concluding the operation, the animals were kept under a heating light for ten minutes. After recovery from the anesthetic, they were housed in individual cages, and water and standard animal feed was made available once they had completely recovered wakefulness. The animals were kept in their individual cages until the sacrifice day, in a climate-controlled environment with temperature and light controls, and they were weighed once a week. No additional care was provided in relation to the wound from the operation and the stoma that was constructed.

On the day preceding the day scheduled for sacrifice, the animals were again kept fasting for 24 hours, except for water. They were again anesthetized, using the same technique described above, and underwent abdominal shaving and antisepsis. Medial laparotomy was then performed, in which the cavity was opened layer by layer. The colon segments with and without transit were removed in their entirety.

The segments removed were opened up longitudinally along the mesocolic margin. They were laid out and attached to a planar cortex surface with the mucous surface uppermost, and were fixed in $10 \%$ formaldehyde solution. The specimens remained in the fixing solution for 24 hours and were then dehydrated in successively increasing concentrations of alcohol and clarified in xylene. The material was then embedded in paraffin blocks and two vertical sections were cut for histopathological studies and computer-assisted image analysis. The sections were stained using the hematoxylin-eosin technique.

The slides were read under an ordinary optical microscope at a final magnification of 200x. The histological parameters were analyzed qualitatively and quantitatively by a pathologist with experience of diseases of the digestive tract who was unaware of the origin of the material and the aims of the study. The following histological parameters were analyzed: thickness of the different layers of the colon wall, characteristics of the mucosal surface, presence of inflammatory infiltrate, inflammatory grade, presence of submucosal vascular congestion and number of caliciform cells.

The length of the crypts of the colon mucosa and the muscle layer thicknesses of the mucosa, submucosa and muscularis propria were measured by computer-assisted image analysis, with evaluation of images from five randomly selected fields. The images selected were captured by a video camera coupled to the optical microscope. They were then processed and analyzed using the NIS-Elements software in a computer (Pentium 4 DC, 1GB RAM, two HDs of 200GB and ASUS video capture board). Measurement of the colon wall layers in the segments with and without intestinal transit was always done at a location where at least six contiguous complete colon crypts could be seen. The final value taken for each measured layer in the segments with and without intestinal transit was the mean of the values found from evaluating the five fields selected.

The mucous surface was analyzed for the presence of erosion or ulceration and was classified as normal, eroded or ulcerated. The intensity of the inflammatory infiltrate was grades as mild, moderate or severe and was differentiated according to the cell type present (lymphocytes, eosinophils or neutrophils) and their intensity (from + to ++++ ). Vascular congestion was classified as absent or present and, when present, as numbers of crosses (from + to ++++ ). The number of caliciform cells was evaluated as normal or increased.

For the variables of appearance of the mucous surface, vascular congestion and inflammatory infiltrate, points from 0 (absent) to 4 (maximum intensity of each variable alone) were attributed. These points were summed to obtain a new study parameter called inflammatory grade, which ranged in value from 0 (absence of inflammation) to 8 (maximum inflammation found). From these summed results, the inflammatory grade was determined for each segment studied. According to the points attributed for the inflammatory grade, the inflammation was stratified as absent $(0)$, mild (1, 2 and 3$)$, moderate $(4,5$ and 6$)$ or severe ( 7 and 8$)$, which was named the degree of inflammation.

The statistical analysis on the results obtained was done by taking a significance level of $5 \%(\mathrm{p} \leq 0.05)$. All the data obtained were expressed as means, standard deviations and the respective confidence intervals and were analyzed using the statistics software SPSS for Windows (version 13.0). The following tests were used: paired Student t, Mann-Whitney, analysis of variance (ANOVA) and Pearson or Spearman correlations.

\section{Results}

Figures 1, 2, 3 and 4 shows the measurements obtained from computerized morphometry on the colon mucosal crypt lengths and muscle layer thicknesses of the muscularis mucosa, submucosa and muscularis propria, in the segments with and without transit in the different experimental groups.

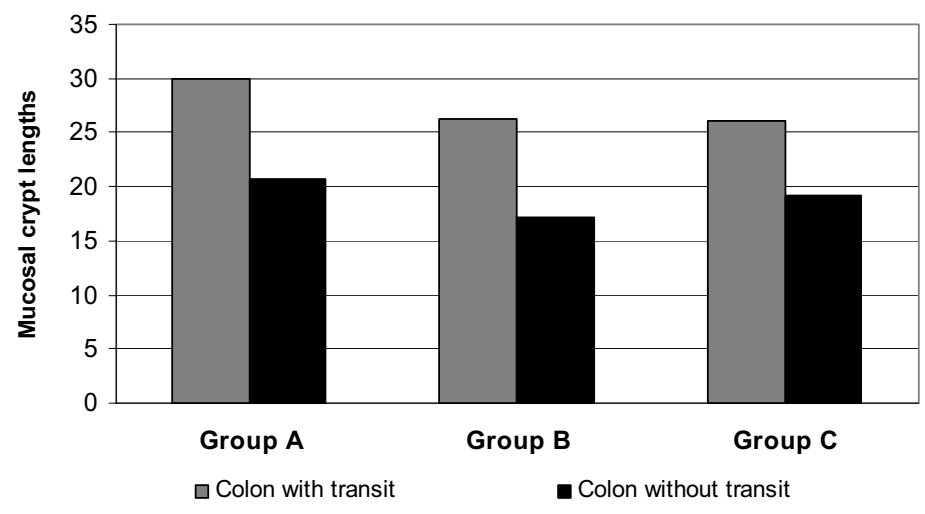

FIGURE 1 - Measurements obtained from computerized morphometry on the colon mucosal crypt lengths, in the segments with and without intestinal transit in the experimental groups. Data is present as mean of micrometers. Student $t$ test: $p<0.0001$ for all groups. 


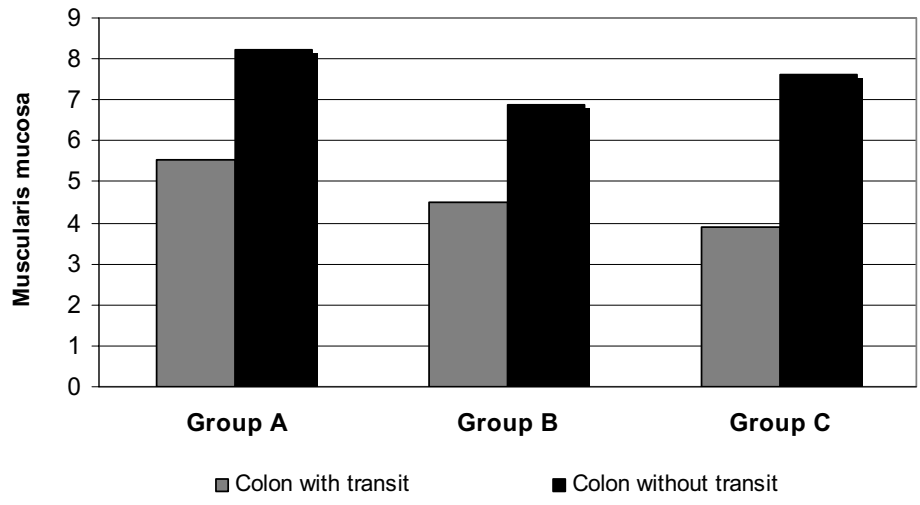

FIGURE 2 - Measurements obtained from computerized morphometry on the thickness of the colon muscularis mucosa, in the segments with and without intestinal transit in the experimental groups. Data is present as mean of micrometers. Student $t$ test: $p<0.0001$ for all groups.

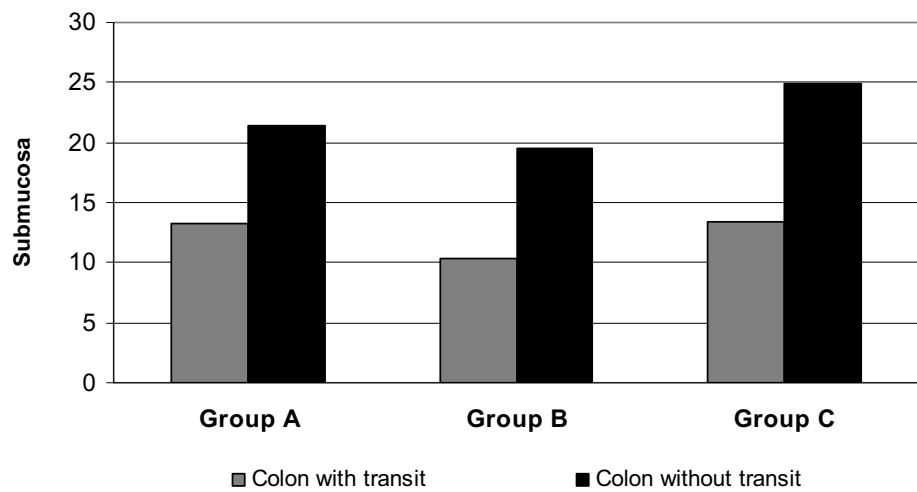

FIGURE 3 - Measurements obtained from computerized morphometry on the thickness of the colon submucosa, in the segments with and without intestinal transit in the experimental groups. Data is present as mean of micrometers. Student $t$ test: $\mathrm{p}<0.0004$ for group A; $p<0.0001$ for groups $\mathrm{B}$ and $\mathrm{C}$.

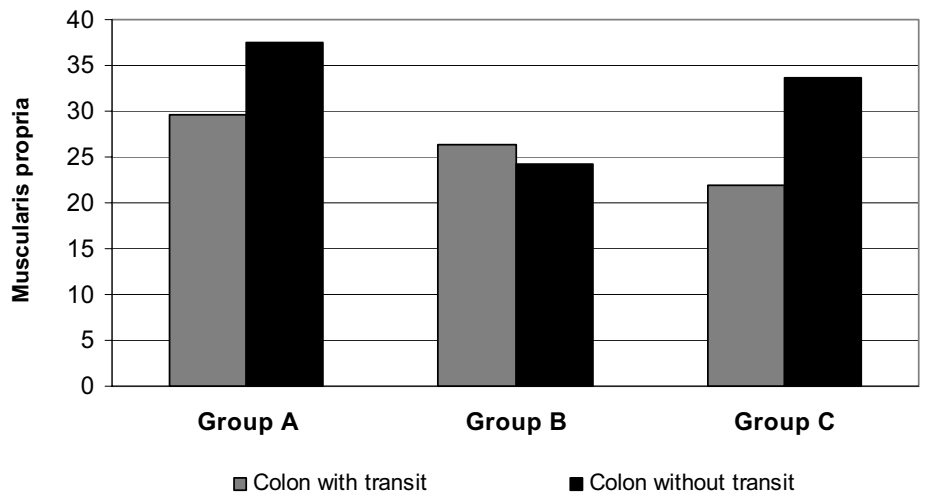

FIGURE 4 - Measurements obtained from computerized morphometry on the thickness of the colon muscularis propria, in the segments with and without intestinal transit in the experimental groups. Data is present as mean of micrometers. Student t test: $\mathrm{p}<0.01$ for group A; $\mathrm{p}<0.0001$ for group C.
Figures 5 and 6 compares the presence of mucosal ulcerations and inflammatory grade, in the segments with and without intestinal transit in the different experimental groups.

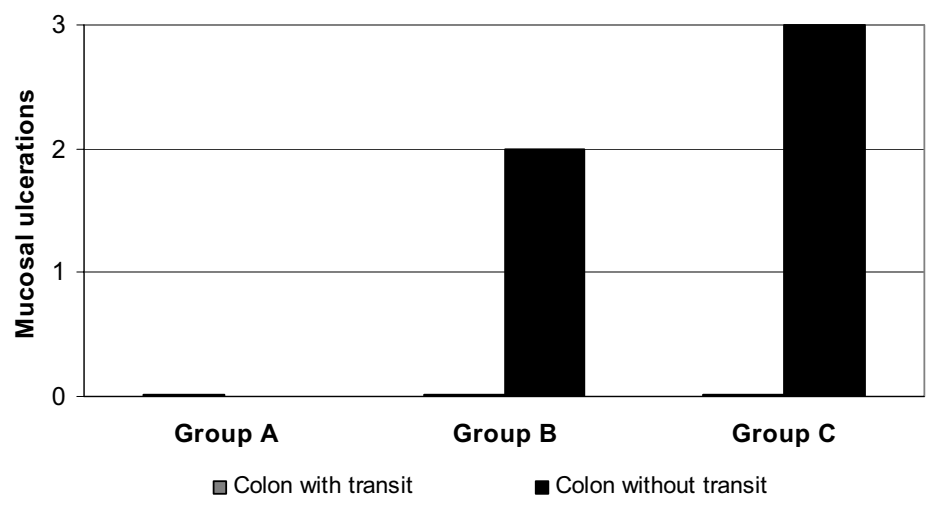

FIGURE 5 - Compares the presence of mucosal ulcerations, in the segments with and without intestinal transit in the different experimental groups. Data is present as median. Mann-Whitney test: $\mathrm{p}<0.02$ for group $\mathrm{B} ; \mathrm{p}<0.008$ for group $\mathrm{C}$.

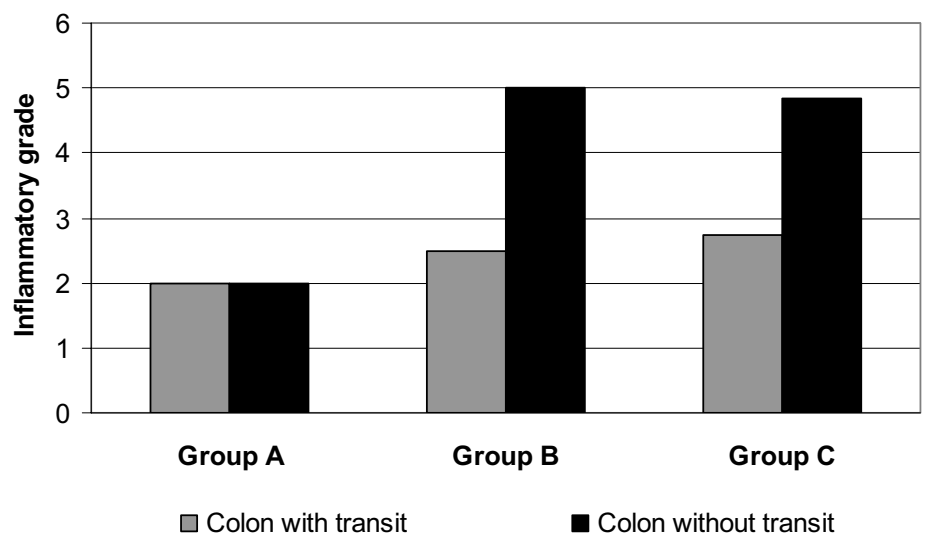

FIGURE 6 - Compares the inflammatory grade, in the segments with and without intestinal transit in the different experimental groups. Data is present as median. Mann-Whitney test: $\mathrm{p}<0.03$ for group $\mathrm{B} ; \mathrm{p}<0.01$ for group $\mathrm{C}$

Figure 7 shows the characteristics of the intestinal mucosal surface, in the segments with and without transit. 


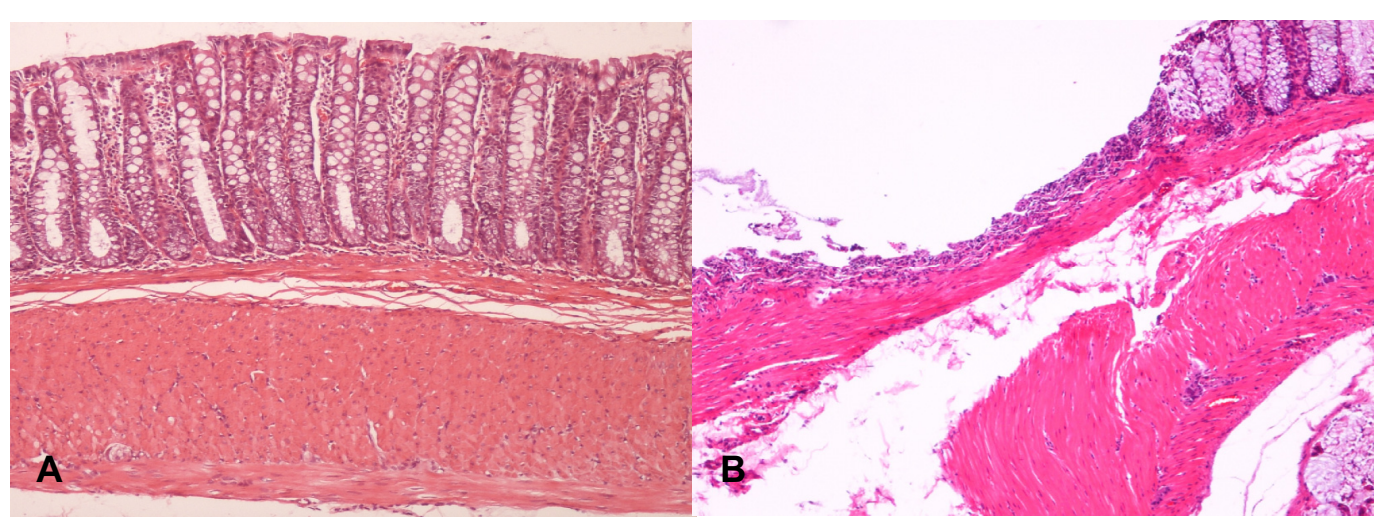

FIGURE 7 - Characteristics of the intestinal mucosal surface, in the segments with and without transit. A- Mucosal surface in the colon with intestinal transit. B- Deep ulcer in the mucosal surface of the colon without intestinal transit (H.E - 200x)

Figure 8 shows the variance of the mean values measured in the different intestinal wall layers, in the segments without transit, in relation to the different durations of exclusion considered.

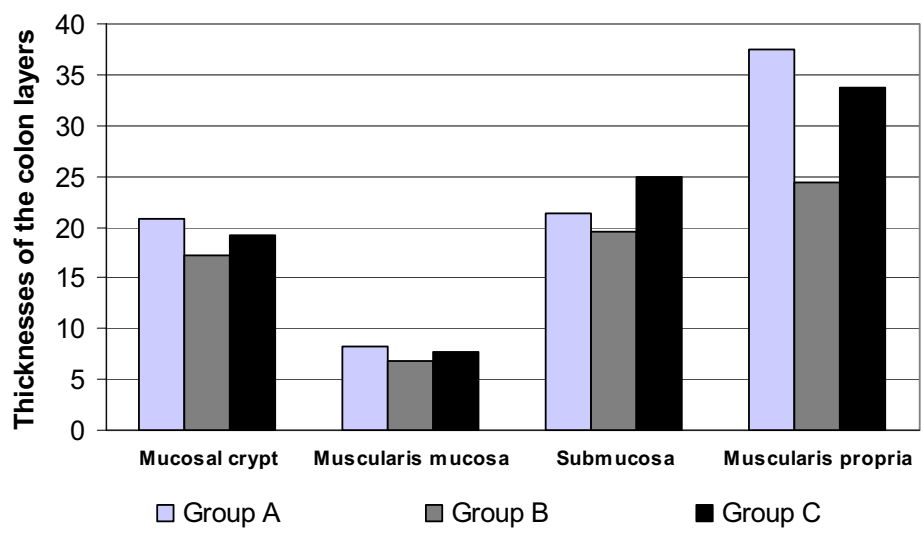

FIGURE 8 - Variance of the thicknesses of all colon lawyers, in the segments with and without intestinal transit in the different experimental groups. Data is present as mean of micrometers. One way analysis of variance (ANOVA) + Newman-Keuls test: $\mathrm{p}<0.05$ for mucosal crypt; $\mathrm{p}<0.01$ for muscularis mucosa (Group A x Group B); $\mathrm{p}<0.05$ for submucosa (Groups A and B x Group C); $<<0.01$ for muscularis propria (Group A x Group B and Group B x Group C).

Table 1 shows the correlations between the study variables and the different durations of intestinal transit exclusion in the segments without transit.

TABLE 1 - Correlations between the studied variables and the length of time without transit in the colon segments without fecal transit.

\begin{tabular}{lccc}
\hline & \multicolumn{3}{c}{ Colon without intestinal transit } \\
\cline { 2 - 4 } & Pearson correlation & Spearman correlation & $\mathbf{p}$ \\
\cline { 2 - 4 } Mucosal crypt lengths & -0.337 & - & 0.06 \\
Thicknesses of the muscularis mucosa & -0.235 & - & 0.21 \\
Thicknesses of the submucosa & 0.460 & - & $0.01^{*}$ \\
Thicknesses of the muscularis propria & -0.372 & - & $0.04^{*}$ \\
Mucosal ulcerations & - & 0.412 & $0.02^{*}$ \\
Vascular congestion of the submucosal layer & - & 0.410 & $0.04^{*}$ \\
Caliciform cells & - & 0.386 & $0.03^{*}$ \\
Inflammatory infiltrate & - & 0.470 & $0.009^{*}$ \\
Inflammatory grade & - & 0.362 & $0.04^{*}$
\end{tabular}

Pearson and Spearman correlation test; $r=$ Pearson coeficient; $r$ s $=$ Spearman coefficient; $*=$ significant

\section{Discussion}

DC is an inflammatory process that affects colon and rectum segments that do not have intestinal transit ${ }^{1,10}$. This disease presents a varied clinical picture and, while most patients evolve asymptomatically, it is estimated that 30 to $50 \%$ become symptomatic as the duration of exclusion increases. Symptomatic patients complain of rectal pain, evacuations with blood and mucus in the feces, tenesmus, low fever and, more rarely, fistulas. Endoscopic examination of the excluded segment identifies the disease in all patients after periods of time ranging from three to 36 months $^{1,10}$.

A variety of theories have been put forward to explain the etiopathogenesis of DC. Prominent among these is a theory that relates the appearance of this disease to decreased quantities of SCFAs in the intestinal lumen $5,6,12,13$. SCFAs are the main energy source for colonocytes and account for approximately $80 \%$ of the energy needs of the colon epithelium ${ }^{14}$. In colon segments without transit, absence of the fecal bolus impedes the formation of SCFAs and also their absorption and use by the epithelial cells. SCFAs cause greater blood flow to the intestinal wall through diminishing the resistance of the arterioles of the colon and rectum. They promote adhesion between the colonocytes, increase sodium and water absorption, stimulate normal growth of the colon epithelial cells, influence motility and favor healing of intestinal wall lesions ${ }^{15,16,17}$. SCFAs play a protective role in relation to neoplasia development because their antiproliferative action interferes in the cell differentiation process, thereby favoring apoptosis ${ }^{17,18}$. In segments without intestinal transit, glutamine (a secondary energy substrate for the epithelium that is mainly supplied by the blood) comes to have a primary role and may be used in preference to glucose as an energy source ${ }^{19}$

DC is diagnosed by means of histopathological examination of mucosal fragments obtained from endoscopic examination. The appearance of the mucosa in excluded colon segments seen via endoscopy may go from macroscopically normal to different degrees of inflammation with erythema, friability, erosion with spontaneous bleeding, edema or inflammatory polyps $^{5,7}$. In more severe cases, aphthoid 
ulcers that are practically indistinguishable from those found in inflammatory intestinal diseases may form ${ }^{20}$. Such characteristics, particularly in patients undergoing intestinal deviation as a result of complications in inflammatory diseases, cause problems in the differential diagnosis between exacerbation crises in preexisting inflammatory diseases and the development of DC, which makes it difficult to indicate whether intestinal transit should be reestablished ${ }^{6}$.

Since the initial description of DC, studies have been demonstrating the main clinical, endoscopic and therapeutic characteristics of this condition ${ }^{1-7}$. Nevertheless, controversies still remain with regard to the histopathological changes in the colon wall in the absence of intestinal transit ${ }^{2,7}$. Evaluations carried out on biopsies from excluded colon segments have demonstrated a variety of histological changes, and no characteristic pattern has been found for $\mathrm{DC}^{2}$. The findings most commonly described include nonspecific chronic inflammation, with or without formation of crypt abscesses, diffuse nodular lymphoid hyperplasia, cryptitis, lymphocyte infiltrate, presence of some neutrophils in the lamina propria and mucin depletion in the mucosal epithelium ${ }^{10}$. The inflammatory infiltrate is composed mainly of plasmatic cells, with small numbers of lymphocytes, macrophages and eosinophils, and it is usually confined to the mucosa. More rarely, it may extend to the submucosa ${ }^{2,21}$. Aphthoid ulcers, abscesses, atrophy and distortion of the crypt architecture and metaplasia of the Paneth cells are alterations found in more severe cases ${ }^{2,6}$. Most of these alterations regress completely after reestablishment of the intestinal transit.

Notwithstanding all the known evidence, few studies have so far evaluated DC experimentally ${ }^{9,10,11}$. Although the microscopic structure of the intestinal wall in rats is similar to that of humans, studies evaluating histological changes have generally been carried out in humans and thus they have been subject to interpretational variations due to sample heterogeneity. The use of rats as an experimental model for DC has been proposed, although some authors have not considered this to be an ideal experimentation animal ${ }^{10,11,15}$.

Studies on the histological changes found in DC cases have generally been carried out subjectively. They have depended on and varied with the pathologist's experience in analyzing the specimens. The possibility of using an image analysis method that allows objective evaluation (less subjectivity in interpreting the changes) makes the results more trustworthy and gives greater uniformity to the descriptions of the different histopathological characteristics. Variables that can be quantitatively evaluated, such as colon crypt length, thicknesses of the different layers of the intestinal wall and number of caliciform cells can be determined objectively, thereby enabling conclusions that are more precise. Computer-assisted analysis has been used with various objectives and, in relation to conventional methods, it has the advantage of enabling fast and objective quantitative evaluation of the microscopic structures $^{22,23}$. Few studies have evaluated inflammatory alterations in the colon wall of intestinal segments that have been taken out of function, by means of morphometric analysis methods ${ }^{9,11,15}$.

The length of the colon mucosal crypts has already been measured in humans and animals with $\mathrm{DC}^{2,10}$. Geraghty et al. ${ }^{2}$ analyzed the histopathological characteristics of 15 patients with DC and found that in $53.3 \%$ of the cases there was atrophy of the intestinal crypts and that $80 \%$ of the cases had distortions of the normal architecture. Keli et al. ${ }^{10}$ studied intestinal segments of rats that had not had transit for six and seventeen weeks and showed that there was a significant reduction in the colon mucosal crypt length in the intestinal segment that had been excluded from transit. They correlated this reduction with the duration of exclusion from measurements made with the aid of computer-assisted image analysis software, Lopes-Paulo et al. ${ }^{11}$ found a significant reduction in crypt length in colon segments without transit in rats. They also observed that, in the segments without transit, the partial volume of the mucosa was significantly smaller in the group with deviation than in the control group. Kissmeyer-Nielsen et al..$^{15}$ found that there were significant reductions in the weight of the colon mucosa, by $10 \%$ after one week, $21 \%$ after two weeks, $37 \%$ after four weeks and $31 \%$ after twelve weeks of intestinal transit exclusion. They observed that the atrophy of the mucosal layer reached significant levels two weeks after the deviation and reached a peak four weeks after the deviation, stabilizing thereafter ${ }^{14}$. Likewise, the present study found a significant reduction in colon mucosal crypt length, comparing segments with and without intestinal transit, independent of the duration of exclusion. The present study demonstrated that there was a significant reduction in colon crypt length in the colon segment without transit after six weeks of exclusion, which reached its lowest value after twelve weeks. Although the animals subjected to transit exclusion lasting 18 weeks presented higher values than after 12 weeks, their values continued to be lower than in the animals with six weeks of exclusion. Comparison of the colon crypt lengths in the animals subjected to exclusion for six weeks with the lengths in the animals subjected to deviation for 12 and 18 weeks showed that the reduction in crypt length varied as the duration of exclusion increased. Studies have been demonstrating that irrigation of segments excluded from intestinal transit (using solutions rich in SCFAs) and reconstruction of the transit may significantly reverse the atrophy of the colon crypts. Such studies have recommended the use of SCFAs for patients undergoing intestinal deviation ${ }^{6,12}$.

The muscularis of mucosa layer was seen to present increased thickness in the segments without intestinal transit, independent of the duration of exclusion considered. However, the animals subjected to exclusion for twelve weeks presented significantly less mucosal muscle layer thickness in the excluded segments than did the animals subjected to exclusion for six weeks. After the twelfth week, the thickness of this layer returned to values close to the six weeks values. These findings were in agreement with those of Kissmeyer-Nielsen et al. ${ }^{15}$ who found a $34 \%$ reduction in mucosal muscle layer weight after twelve weeks of intestinal deviation. In the present study it was not possible to demonstrate a linear correlation between the duration of exclusion and modifications to the thickness of the mucosal muscle layer.

One of the most evident endoscopic characteristics of DC is the presence of erosion and ulceration of the intestinal mucosa, which may facilitate the migration of antigens from inside the lumen to the bloodstream. Lim et al. ${ }^{24}$ believed that absorption of antigens by ulcerated mucosa in excluded colon segments may lead to the synthesis of colon antimucosal antibodies, thereby triggering inflammatory alterations in the parts of the colon that have intestinal transit, similar to those found in ulcerative colitis. Experimental studies have been demonstrating that modifications to the normal architecture of the colon mucosa, in segments without transit, may cause changes to the intestinal barrier, although such changes do not necessarily increase bacterial translocation ${ }^{25}$. Glotzer et al. ${ }^{1}$ detected the presence of alterations in the intestinal mucosa in $100 \%$ 
of the patients they studied and related this to the duration of exclusion. Nevertheless, other authors have only found lesions in the colon mucosa in $76 \%$ and $53.3 \%$ of the cases $^{2,26}$. Keli et al. ${ }^{10}$ found modifications to the epithelial surface in excluded segments only in animals subjected to 17 weeks of transit exclusion and, even then, there was no significant relationship with the duration of exclusion. Biondo-Simões et al. ${ }^{9}$ reported the presence of surface ulcers in $31.43 \%$ of the intestinal segments studied. Only the mucosal layer was affected and this was unrelated to the duration of exclusion. Although unaffected colon mucosa is considered to be an infrequent finding in DC in rats, it was seen in the present study that after twelve weeks of exclusion there were increased amounts of erosion and ulceration in the colon mucosa, which was correlated with the duration of exclusion of the intestinal transit. In three animals that were subjected to intestinal deviation for 18 weeks, the formation of deep ulcers reaching the muscularis of the mucosa was identified. The different findings in the literature can be explained by the different durations of exclusion and analysis methodology utilized.

The presence of vascular congestion in the lamina propria is considered to be a sign suggestive of inflammation ${ }^{10}$. Even though it is difficult to quantify vascular congestion, it may when identified emphasize the presence of inflammatory infiltrate. An experimental study demonstrated that, in intestinal segments without transit, there was significantly greater vessel congestion in the submucosa than in segments with preserved transit ${ }^{10}$. Lopez-Paulo et al. ${ }^{11}$ observed a significant increase in partial volume of the submucosa in the intestinal segment without transit and attributed this finding to a possible increase in conjunctive tissue and vascular congestion in the submucosa. Kissmeyer-Nielsen et $a l .{ }^{15}$, however, did not find variations in the weight of the submucosal layer in segments without transit. In the present study, it was found from comparing the segments with and without intestinal transit that there was a significant increase in the thickness of the submucosal layer in segments excluded from the transit, and this correlated with the duration of exclusion, reaching its greatest value after 18 weeks. On the other hand, although the vascular congestion of the submucosa increased with increasing duration of exclusion, it was not possible to demonstrate any significant increase in vascular congestion of the submucosal layer comparatively between the segments with and without transit. Nevertheless, the vascular congestion of the submucosa correlated with the duration of exclusion, presence of inflammatory infiltrate, degree of inflammation and the proposed scale for inflammatory grade.

Infiltration of inflammatory cells into the lamina propria is a frequent finding in DC cases. However, quantification of such findings must be treated with caution, since there is some degree of infiltrate in normal colon mucosa ${ }^{10}$. With the aim of diminishing the subjectivity of this interpretation, some authors have proposed quantitative and qualitative analysis of the cells present in the inflammatory infiltrate ${ }^{27}$. In the present study, it was decided to take the variables normally considered in characterizing the inflammatory process together, by means of a graded scale. Through this combined analysis, it could be seen that there was greater inflammatory activity in the colon without transit, after 12 and 18 weeks of exclusion. It was also found that the inflammatory grade and the degree of inflammation correlated with the duration of exclusion of the intestinal transit.
Violi et al. ${ }^{28}$ studied the thickness of the muscularis propria layer in colon segments with and without transit and found a significant increase in the segments excluded from the intestinal transit. In a different manner, Kissmeyer-Nielsen et al. ${ }^{15}$ identified reductions of up to $48 \%$ in the thickness of the muscularis propria layer in the excluded segments, in relation to the segments in which the intestinal transit was preserved. In the present study, while removing the specimens, it was seen macroscopically that the colon segments without transit had contracted, with reduced diameter and length. This observation was more evident in the animals subjected to 18 weeks of deviation of the intestinal transit. Comparing segments with and without intestinal transit, it was seen that the muscularis propria layer in the excluded segments presented significantly increased thickness after six and 18 weeks. On the other hand, there was a reduction in the muscularis propria layer in the excluded segments of animals subjected to 12 weeks of intestinal deviation. It was observed that the variation in muscle layer thickness in segments without intestinal transit presented an inverse relationship with duration of exclusion, up to the twelfth week.

Modifications to mucus secretion seem to be one of the most important elements in DC. Changes in the secretions through non-functional mucosa are alterations of use in diagnosing the disease. The number of caliciform cells reflects the state of the mucus secretions and indirectly the activity of these cells. Keli et al. ${ }^{10}$ did not find any changes in the number of caliciform cells when they compared segments without transit after different lengths of time of exclusion. From histochemical analysis of the mucin expression pattern of the intestinal mucosa, those authors found that in the animals with preserved transit, there was tissue expression of sulfomucins in the cells located in the upper third of the colon crypts and sialomucins in the lower two thirds. In the segments without transit, the sialomucins disappeared and the cells only presented sulfomucin expression, which increased in intensity with increasing duration of exclusion. Those authors suggested that this result was related to caliciform cell maturation, such that they were only capable of producing sulfomucins. Biondo-Simões et al. ${ }^{11}$ studied the caliciform cell concentrations in colon segments of rats without transit for one, two, four and eight weeks and found significantly greater concentrations of caliciform cells after one and two weeks of exclusion, in comparison with segments subjected to longer duration of exclusion. The present study showed that there were increased numbers of caliciform cells in the animals subjected to 18 weeks of exclusion, although this increase did not present significance. It also showed a significant correlation between the duration of exclusion and the number of caliciform cells found in the intestinal mucosa of the segments excluded from the transit, regardless of the decrease in intestinal crypt thickness.

The results from the present study have shown that DC is an inflammatory disease that affects all layers of the intestinal wall of segments without transit. Considering the greater incidence of fistulas when reconstructing the intestinal transit in DC patients, this greater incidence may be related to the inflammatory alterations seen in the excluded colon ${ }^{15}$. Since reestablishment of the transit completely reverses the DC in these patients, it may be that reconstitution ought to be done as early as possible, thereby avoiding carrying out anastomoses in tissue with increasing degrees of inflammation and structural alterations to the colon wall ${ }^{29}$. 


\section{Conclusions}

The results from the present study allow the conclusion that histological alterations occurred in all layers of the colon wall, in the segments excluded from intestinal transit, and that the inflammatory reaction became progressively greater as the duration of exclusion increased.

\section{References}

1. Glotzer DJ, Glick ME, Goldman H. Proctitis following diversion of fecal stream. Gastroenterology. 1981;80:438-41.

2. Geraghty JM, Talbot IC. Diversion colitis: histological features in the colon and rectum after defunctioning colostomy. Gut. 1991;32:1020-3.

3. Habr-Gama A, Teixeira MG, Vieira MJF, Miléu LF, Laurino Neto R, Pinotti HW. Operação de Hartmann e suas conseqüências. Rev Bras Coloproctol. 1997;17:5-10.

4. Barreto Neto PF, Morais DCR, Tavares GA, Bispo DJS, Souza Jr. JMM. Trauma colorretal: estudo retrospectivo. Rev Bras Coloproctol. 2002:170-4. 5. Giardiello FM, Lazenby AJ, Bayless TM. The new colitides: collagenous, lymphocytic, and diversion colitis. Gastroenterol Clin North Am. 1995; 24: 717-29.

6. Kiely EM, Ajayi NA, Wheele RA, Malone M. Diversion procto-colitis: response to treatment with short-chain fatty acids. J Pediatr Surg. 2001;36:1514-7.

7. Edwards CM, George B, Warren B. Diversion colitis: new light through old windows. Histopathology. 1999;34:1-5.

8. Velazquez OC, Lederer HM, Rombeau JL. Butyrate and colonocyte: production, absorption, metabolism and therapeutic implications. Adv Exp Med Biol. 1997;427:123-34.

9. Biondo-Simões MLP, Greca FH, Abicalaffe MD, Colnaghi MC, Mattos e Silva E, Yamasaki ES, Smaniotto G. Colite do cólon excluso: modelo experimental em ratos. Acta Cir Bras. 2000;15(supl 3):7-11.

10. Keli E, Bouchoucha M, Devroede G, Carnot F, Ohrant T, Cugnenc PH. Diversion-related experimental colitis in rats. Dis Colon Rectum. 1997;40:222-8.

11. Lopes-Paulo F. Alterações estruturais na mucosa do cólon derivado: estudo estereológico experimental em ratos. Rev Bras Coloproctol. 2002;22:164-9.

12. Neut C, Guillemot F, Gower-Rousseau C, Biron N, Cortot A, Colombel JF. Treatment of diversion colitis with short-chain fatty acids: bacteriological study. Gastroenterol Clin Biol. 1995;19:871-5.

13. Oliveira-Neto JP, Aguilar-Nascimento JE. Intraluminal irrigations with fibers improves inflammation and atrophy in diversion colitis. Nutrition. 2004;20:197-9.
14. Roediger WE. The starved colon: diminished mucosal nutrition, diminished absorption, and colitis. Dis Colon Rectum. 1990;33:858-62.

15. Kissmeyer-Nielsen P, Christensen H, Laurberg S. Diverting colostomy induces mucosal and muscular atrophy in rat distal colon. Gut. 1994;35:1275-82.

16. Mortensen FV, Hessov I, Brike H, Korsgaard N, Nielsen H. Microcirculatory and trophic effects of short chain fatty acids in the human rectum after Hartmann's procedure. Br J Surg. 1991;78:1208-11.

17. Pinto A, Fidalgo P, Cravo M, Midões J, Chaves P, Rosa J, Brito MA, Leitão CN. Short chain fatty acids are effective in short-term treatment of chronic radiation proctites: randomized double-blind, controlled trial. Dis Colon Rectum. 1999;42:788-95.

18. Velazquez OC, Lederer HM, Rombeau JL. Butyrate and colonocyte: production, absorption, metabolism and therapeutic implications. Adv Exp Med Biol. 1997;427:123-34.

19. Roedger WE. Utilization of nutrients by isolated epithelial cells of the rat colon. Gastroenterology. 1982; 83:424-9.

20. Korelitz BI, Cheskin LJ, Sommers SC. The fate of the rectal segment after diversion of the fecal stream in Crohn's disease: its implication for surgical management. J Clin Gastroenterol. 1985;7:37-43.

21. Roe AM, Warren AJM, Brodribb CB. Diversion colitis and involution of the defunctioned anorectum. Gut. 1993;34:382-5.

22. Priolli DG. Margarido NF, Martinez CAR, Rotta CM, Stephani SM. Edema quantification by computerized morphometry as an evaluation parameter for the resistance of colon anastomoses. Acta Cir Bras. 2003.18:398-406.

23. Martinez CAR, Waisberg J, Palma RT, Silva FZ, Cimerman G, Goffi FS. Morphometric study of gastric mucosa in dogs submitted to proximal gastric vagotomy, splenectomy or proximal gastric vagotomy associated with splenectomy. Acta Cir Bras. 2002;17(5): 289-98.

24. Lim AG, Langmead FL, Feakins RM, Rampton DS. Diversion colitis: a trigger for ulcerative colitis in the in-stream colon. Gut. 1999;44:279-82. 25. Pinto Júnior FEL, Brandt CT, Medeiros AC, Oliveira AJF, Jerônimo SM, Brito HMF. Bacterial translocation in rats nonfunctioning diverted distal colon. Acta Cir Bras. 2007;22:195-201.

26. Orsay CP, Kim DO, Pearl RK, Abcarian H. Diversion colitis in patients scheduled for colostomy closure. Dis Colon Rectum. 1993;36:366-7.

27. Jenkins D, Goodall A, Drew K, Scot BB. What is colitis? Statistical approach to distinguishing clinically important inflammatory change in rectal biopsy specimens. J Clin Pathol. 1988;41:72-9.

28. Violi V, Cobianchi F, Adami M, Torri T, Ferraro G, Roncoroni L. Human defunctionalized colon: a histopathological and pharmacological study of muscularis propria in resection specimens. Dig Dis Sci. 1998;43:616-23.

29. Pearce NW, Scott SD, Karran SJ. Timing and method of reversal of Hartmann's procedure. Br J Surg. 1992;79:839-41.

\section{Correspondence:}

Carlos Augusto Real Martinez

Conflict of interest: none Financial source: FAPESP

Process 2006/02306-6

Rua Rui Barbosa, 255/32

09190-370 Santo André - Sao Paulo Brazil

Phone: (55 11)4438-9203

caomartinez@uol.com.br

Received: March 18, 2008

Review: May 20, 2008

Accepted: June 23, 2008

\section{How to cite this article}

Sousa MV, Priolli DG, Portes AV, Cardinalli IA, Pereira JA, Martinez CAR. Evaluation by computerized morphometry of histopathological alterations of the colon wall in segments with and without intestinal transit: experimental study on rats. Acta Cir Bras. [serial on the Internet] 2008 Sept-Oct;23(5). Available from URL: http://www.scielo.br/acb 